\title{
A boa razão e o iluminismo português
}

The good reason and the portuguese enlightenment

\section{Eduardo Teixeira de Carvalho Junior}


Resumo: Neste artigo, pretende-se discutir a ideia de "boa razão" como um termo-chave no contexto do iluminismo português. Como se sabe, o rei Dom José promulgou a famosa lei de 18 de agosto de 1769 , que pelo conteúdo de suas proposições passou a ser chamada de "lei da boa razão". Esta lei acabou servindo para fazer referência às medidas implementadas pelo Marquês de Pombal no campo do direito, representando um alinhamento do reino com as tendências do jusnaturalismo moderno, ligada ao processo de centralização do poder e de laicização e organização do Estado a partir de uma racionalidade mais adequada aos novos tempos. Na tentativa de melhor compreender o sentido que este termo assumiu no contexto lingüístico do século XVIII português, discutem-se alguns usos e significados deste termo em documentos do século XVIII. Além da "lei da boa razão”, serão analisados documentos da Reforma da Universidade de Coimbra e o Verdadeiro Método de Estudar de Luiz António Verney. Este artigo também visa contribuir para o projeto de um glossário de termos setecentistas do grupo de pesquisa Cultura e Educação nos Impérios Ibéricos (CEIbero).

Palavras-chave: Boa razão; Iluminismo português; Direito natural; Jusnaturalismo; Verney.

Abstract: The aim of this article is to discuss the idea of "good reason" as a key term in the context of the Portuguese Enlightenment. As is well known, King Dom José enacted the famous law of August 18, 1769, which, due the content of his propositions, became known as the "law of good reason". This law ended up serving to refer to the measures implemented by Marquês de Pombal in the field of Law, representing an alignment of the kingdom with the modern tendencies of jusnaturalism, connected to the process of centralization of power, secularization and organization based on a rationality adequate to the new times. In an attempt to better understand the meaning that this term assumed in the linguistic context of the $18^{\text {th }}$ century in Portugal, some uses and meanings of this term 
are discussed in $18^{\text {th }}$ century documents. In addition to the "law of good reason", it will be analyzed some Reform documents of the University of Coimbra and LuizAntónioVerney's true method of studying. This article also aims to contribute to a glossary of eighteen century terms for the Culture and Education in the Iberian Empires research group (CEIbero).

Keywords: Good reason; Portuguese enlightenment; Natural law; Jusnaturalism; Verney. 
No encontro do grupo de pesquisa "cultura e educação nos impérios ibéricos" (CEIbero) realizado no ano de 2017 na cidade de Diamantina apresentei um trabalho intitulado "A dimensão política do conceito de método no século XVIII português”. Nesta comunicação procurei argumentar que o conceito de método foi um termo-chave no contexto lingüístico do iluminismo português, pois serviu para demarcar duas grandes correntes ideológicas que marcaram a mentalidade portuguesa entre os séculos XVII e XVIII, a saber, uma corrente identificada com as "luzes" e outra de matriz escolástico-jesuíta. De forma geral representa o conflito entre o moderno e o tradicional na cultura portuguesa. Naquela ocasião a ilustre professora Ana Cristina Araújo levantou a hipótese de que o conceito de "boa razão" também poderia ser pensado como um termochave para se compreender este processo, o que acabei acatando como hipótese de pesquisa.

Como se sabe, o rei Dom José, seguindo conselhos de seus ministros, promulgou a famosa Lei de 18 de agosto de 1769, que pelo conteúdo de suas proposições passou a ser chamada de "lei da boa razão". A alcunha de "lei da boa razão" só passou a ser utilizada para fazer referência a esta lei após a publicação dos comentários de José Homem Correia Telles em 1824 (TELLES, 1824). Talvez esta interpretação de Telles tenha contribuído para fazer com que esta lei se tornasse referência a todo um conjunto de medidas implementadas pelo Marquês de Pombal no campo do direito e da organização do reino. Tratase de um olhar específico em relação ao século XVIII, questão que não tratarei aqui, e que talvez merecesse uma análise, pois sabem os historiadores que o século XVIII não foi tão moderno e racional assim como seria tratado pela posteridade com o epíteto de Era da razão. O caráter despótico de algumas ações políticas do período pombalino podem servir para justificar estas considerações (MAXWELL, 1996). Contudo, o termo "boa razão”, embora pudesse estar mais ligado ao campo jurídico, foi envolvido pelas transformações mais amplas que ocorreram no iluminismo português, como pretendo analisar neste texto.

A "lei da boa razão" representava uma adequação do reino português aos "novos tempos" e reforçava a autoridade do rei seguindo as tendências européias de centralização do poder. No campo jurídico, apontava para um alinhamento com as correntes do jusnaturalismo moderno, ligada ao processo de laicização e organização do Estado a partir da racionalidade moderna. Não vou me ater aqui na questão da efetividade da norma, ou seja, seu impacto na práxis jurídica do Império português, mas tentar identificar de que maneira o termo "boa razão" estava articulado com o ideário iluminista português. 
Tendo como referência o modelo de abordagem da história do pensamento político proposta por Quentin Skinner de analisarmos a maneira como determinados termos são utilizados em diferentes contextos intelectuais, procurarei responder a algumas perguntas: o que significa o termo "boa razão" incluído no texto da lei? Contra qual tipo de razão a "boa razão” se contrapõe? Haveria uma “má razão”? Em que outros contextos, além da lei de 18 de agosto de 1769, o termo “boa razão” foi utilizado? São estas questões que procurarei responder nesta análise.

\section{A boa razão da lei e o direito natural na reforma da universidade}

Em diversos momentos, a mencionada lei faz alusão à necessidade de Portugal acompanhar as práticas jurídicas que vinham sendo objeto de cuidados das “nações polidas da Europa”. Apontava para a necessidade de combater “interpretações abusivas” que fragilizavam a necessária certeza que a justiça e o direito deveriam oferecer para a conservação do "sossego público”. Visava combater posturas antiquadas com que alguns advogados conduziam demandas jurídicas, “animadas por frívolos pretextos tirados das extravagantes sutilezas”, mediante "palavras sediciosas” e "prejudiciais cavilações”.

O termo "boa razão" é mencionado somente no item nono da lei, trecho que remete ao Livro III das Ordenações Filipinas, publicado em 1603. Ressaltase que as Ordenações Filipinas ainda estavam vigendo no século XVIII, e só cairiam em desuso ao longo do século XIX. Neste sentido, a "lei da boa razão" pode ser compreendida como uma alteração do texto de 1603, especificamente na parte que tratava de possíveis lacunas e casos omissos nas leis do reino. A principal fonte do direito português eram as Ordenações, contudo, em casos omissos, elas estabeleciam uma série de recomendações: crimes de pecado deveriam ser julgados pelo direito canônico; caso não fosse matéria de pecado dever-se-ia recorrer às leis romanas (Imperiais, Corpus Iuri Civili) respeitando a seguinte observação: “As quais Leis Imperiais mandamos somente guardar pela boa razão em que são fundadas"; mas, se não houvesse uma resolução por meio de nenhuma destas fontes, recorrer-se-ia às glosas de Acúrcio e Bártolo; em última instância, se o caso permanecesse sem uma solução, recorria-se a uma consulta ao rei, cuja resolução passava a servir de referência para futuros casos semelhantes(ORDENAÇÕES FILIPINAS, 1603, p. 664).

A “lei da boa razão" ratifica algumas recomendações das Ordenações Filipinas e a moderniza conforme os ditames do racionalismo iluminista. De acordo com 
o texto da lei, o princípio da "boa razão", posto pelas Ordenações Filipinas, havia sido corrompido com o passar do tempo. A jurisprudência foi "pondo em esquecimento as Leis Pátrias, fazendo-se uso somente das dos romanos”. Portanto, a "lei da boa razão" reafirma aquele princípio, porém adequando-o aos novos tempos. Muitas das leis romanas haviam sido fundamentadas em diferentes circunstâncias, pois “tiveram por fundamentos outras razões”, baseadas em "particulares costumes dos mesmos Romanos, que nada podem ter de comuns com os das Nações, que presentemente habitam a Europa” (SILVA, $1830 b$, p.4).

A “lei da boa razão" se diferencia em relação ao texto de 1603 na maneira como tratava e reafirmava o princípio da "boa razão", princípio este que já constava nas Ordenações Filipinas, mas que assumiria um significado distinto na lei de 1769 . Tanto no texto de 1603 , como no de 1769 , determinava-se que em casos de lacunas, quando não se encontrava nenhuma resolução nas leis do reino, que se pudesse recorrer ao direito romano sempre que este estivesse de acordo com a "boa razão", contudo, a lei de 1769 alterava o entendimento sobre o princípio da "boa razão” da seguinte maneira:

[...] aquela boa razão, que consiste nos primitivos princípios, que contém verdades essenciais, intrínsecas, e inalteráveis, que a Ética dos mesmos Romanos havia estabelecido, e que os Direitos Divino, e Natural, formalizaram para servirem de Regras Morais, e Civis entre o Cristianismo (SILVA, 1830b, p.5, grifo nosso).

A ideia de boa razão deveria constituir o espírito das leis, "Leis das Nações Cristãs, iluminadas, e polidas" de acordo com os “novos tempos” de luzes das "nações civilizadas". Outra diferença importante em relação ao Código de 1603 é seu caráter laicizante, enfatizando que crimes de pecado "pertencem privativa, e exclusivamente ao foro interior e a espiritualidade da Igreja”, extinguindo qualquer possibilidade de confusão entre a esfera espiritual e a esfera temporal. E contrariando expressamente as Ordenações Filipinas, a “lei da boa razão" determinava que as glosas e opiniões de Acúrsio e Bartolo não pudessem mais ser alegadas em juízo e somente poderiam ser tolerados costumes que seguissem o princípio da "boa razão" e que fossem tão antigos quanto acima de cem anos. Todos aqueles costumes que não atendessem a estes requisitos seriam considerados corruptos e abusivos.

A simples promulgação da lei não seria suficiente para se atingir os efeitos 
desejados pelo governo pombalino, que almejava uma profunda reformulação no quadro administrativo do reino, alinhado com os princípios da utilidade e da racionalidade (SANTOS, 2011). A exigência de adequação ao critério da boa razão, que a princípio poderia ser considerado vago e impreciso, seria melhor explicitado mais tarde, em outros documentos, principalmente nas diretrizes para o ensino do direito apresentadas nos novos Estatutos da Universidade de Coimbra (COSTA, 1996, p.358). Deve-se ainda salientar o caráter antijesuítico destes documentos que, desde a expulsão dos jesuítas do reino, passaram a apontar para o estado de atraso de Portugal em relação às potências europeias e imputavam à Companhia de Jesus toda a causa deste atraso, como já é possível observar no Alvará de Reforma dos Estudos de 28 de junho de 1759(SILVA, 1830a).

Para reparar os “prejuízos” causados pelos jesuítas, o rei institui uma "junta de providência literária” constituída sob a inspeção do Conselho de Estado, representados pelo Cardeal da Cunha e o Marquês de Pombal. O resultado dos trabalhos desta junta foram publicados, em 1771, no Compêndio Histórico da Universidade de Coimbra onde foram listados uma série de "estragos" produzidos pelos jesuítas nos diversos setores da educação, tendo como eixo central o problema do método de ensino utilizado pelos jesuítas, fundado na filosofia escolástica. Os "estragos" haviam começado desde os estudos preparatórios, com destaque para o método de ensino do latim, língua fundamental para o conhecimento das ciências, especialmente as jurídicas, cujas leis estavam escritas nesta língua.A lista de "estragos" era imensa, desde os cursos tradicionais como teologia, direito, medicina e filosofia, estendendo-se para outras disciplinas como retórica, lógica e metafísica. Conforme já havia sido apontado por alguns pensadores portugueses, como Luiz António Verney, as críticas fundamentavam-se no uso de um método considerado atrasado e prejudicial, que envolvia também o desprezo ou ausência de algumas disciplinas consideradas fundamentais, como história, geografia e o ensino da língua grega.

De acordo com o Compêndio, os jesuítas teriam envolvido a jurisprudência do reino português em um "mar de trevas" com o objetivo de destruir e arruinar a nação. Infiltrados nos setores-chave do reino, sobretudo no controle da universidade, permitiram maliciosamente que as leis pátrias "acomodadas no gênio e costumes da nação" e "as únicas adequadas e próprias para manter a paz entre nós e fazer-nos felizes", fossem deixadas de lado para dar lugar ao direito romano, leis promulgadas em um contexto diferente, por um "povo de diverso gênio, de Religião e costumes diferentes” (POMBAL, 2011, p.313). E, 
além disso, as leis eram "contaminadas” pelas opiniões de Acúrsio e Bartolo. Assim, no Compêndio, fica enfatizado a primazia das leis pátrias (Ordenações Filipinas) em detrimento de outras fontes do direito, pois as leis pátrias estariam mais conformes à vontade do rei. Esta diretriz poderia ser compreendida como um dos elementos que constituem o conceito de "boa razão" na legislação pombalina, pois a "boa razão" é, entre outros fatores, aquela que convém ao rei, o único responsável por conservar o reino e a felicidade de seus súditos. Diante de tudo isso:

[...] foi necessária a providentíssima Lei de 22 de Agosto de 1769, que estabeleceu uma Regra normal e segura, com que restituiu e fixou a autoridade das ditas Leis Pátrias e declarou o justo preço do Direito Romano e o uso legítimo que dele se pode ainda fazer no Foro destes Reinos. (POMBAL, 2011, p.317, [sic])

Conforme o trecho citado, o direito romano não é abandonado, mas colocado em segundo plano, podendo ser utilizado com bom senso, ou seja, de acordo com a "boa razão". Outro elemento importante destacado pelo Compêndio é a importância da ética e principalmente do direito natural, que é apontado como “a Disciplina mais útil e a mais necessária com que os Juristas se devem dispor e preparar para fazerem bons progressos nas Ciências Jurídicas". O direito natural, por ser fundamentado na razão natural, possibilita compreender os deveres e obrigações que "a natureza impõe aos homens e aos cidadãos", portando, são considerados a base de todas as leis positivas (POMBAL, 2011, p.256).

Os resultados apresentados no Compêndio serviram de base para a elaboração dos novos Estatutos da Universidade de Coimbra (1772), que foram anunciados pelo rei como o início de uma nova era na história de Portugal. Os novos estatutos foram instituídos por meio de uma "Carta de Roboração" datada de 28 de agosto de 1772, na qual o rei reafirma seu poder expressando que os novos dispositivos de funcionamento da universidade estavam conformes com sua vontade (JOSÉ I, 1772a). O "Rei e Senhor Soberano, que na temporalidade não reconhece na Terra Superior; como protetor da sobredita Universidade”, aprova os novos estatutos que estavam "acomodados ao bem, e aumento da sobredita Universidade; e muito úteis para os progressos das Ciências, e Artes que nela se devem ensinar" (JOSÉ I, 1772b, p.viii).

Nos Estatutos reafirma-se o que havia sido posto na Lei de agosto de 1769, assim como repetido no Compêndio, e chama mais uma vez a atenção para 
a importância do direito natural, como um pré-requisito necessário para o entendimento do direito romano, canônico e pátrio. $O$ direito natural é a cadeira comum para os cursos de direito civil e canônico, considerada subsidiária dos dois. Grócio e Pufendorf são os autores citados como fundamentais para o ensino do direito natural. Mesmo assim, não deveriam ser tomados como autoridades absolutas, o professor teria liberdade para discordar, quando em seu entendimento, estes autores estivessem se desviando da justiça natural. Conforme fica claro na passagem abaixo, a razão torna-se o principal fundamento e guia para a compreensão e entendimento do justo:

\begin{abstract}
A razão será a sua primeira Mestra; o Oráculo, a que ele primeiro recorra, e que primeiro consulte. Esta é a fonte de toda a Legislação da Natureza. Dela deduzirá os preceitos naturais, e por Ela os demonstrará; pondo-os na maior luz, e evidencia, de que eles possam ser suscetíveis (JOSÉ I,1772c, p.113).
\end{abstract}

Nos Estatutos da Universidade de Coimbra, há uma proposta ampla de reformulação das disciplinas, dos conteúdos e dos métodos de ensino, que, de certa forma, constitui uma série de diretrizes para formar homens com os conhecimentos e características que os tornassem úteis a administração do reino; em outras palavras, homens dotados de "boa razão". Nos Estatutos da Universidade de Coimbra, não se nega apenas o método dos escolásticos, mas também a “Moral dos Escolásticos”, por ser fundamentada na ética de Aristóteles, pelo seu ateísmo e por não reconhecer na Moral nenhuma proposição de “eterna verdade; nem admitiu Lei alguma natural no seu verdadeiro sentido” (JOSÉ I, $1772 b$, p.134). De acordo com os Estatutos, embora os escolásticos fizessem uso da razão, esta não poderia ser considerada uma "boa razão” devido aos abusos cometidos e "por se governarem nos seus raciocínios, não pela razão bem dirigida, e ilustrada pela luz da revelação; mas sim escurecida pela corrupção da natureza, e cegamente guiada pelos seus próprios caprichos, e paixões.” (JOSÉ I, 1772b, p.132).

A erudição, por exemplo, superestimada no modelo de ensino escolástico, não é uma qualidade necessária ao professor de direito natural. Pelo contrário, pode até mesmo ser prejudicial e atrapalhar a clareza do entendimento. Mesmo que a erudição pudesse ser útil para relembrar fatos históricos, para ilustrar ou comprovar preceitos naturais, ao se "entregar a leitura" e ao "esforço de muito ler”, o sujeito se “esquece de meditar” (JOSÉ I, 1772c, p.134). Portanto, o 
princípio da boa razão envolve diretrizes na forma da leitura e interpretação da lei, o jurista não deveria se apegar tanto ao texto, mas sim a sua aplicabilidade e coerência com as necessidades dos "novos tempos".

\section{A boa razão: entre o seiscentos e o setecentos}

Qual a diferença do uso feito do termo "boa razão" nas Ordenações, no século XVII, e na lei de 1769? Conforme aponta Nuno Espinosa Gomes da Silva, até então a razão era utilizada para a correta interpretação da lei, "era uma razão exegética, uma razão que rasteja, colada ao texto” (SILVA, 2006, p.455). Ou seja, trata-se da razão escolástica. Porém, era preciso subordinar a ordem jurídica tradicional ao novo tempo e aos interesses dos monarcas, "onde antes a razão se contentava em descobrir a "verdade" do texto jurídico, agora, a razão, insatisfeita, levanta os olhos do texto, despreza-o e procura, antes, uma "verdade" intemporal" (SILVA, 2006, p.457 [sic]). A lei procurava induzir uma interpretação que fosse adequada aos interesses do governo; somente assim uma interpretação da lei poderia ser considerada legítima. O objetivo era evitar outras interpretações, que embora pudessem ser consideradas legítimas sobre o ponto de vista seiscentista, já não estavam mais de acordo com o ponto de vista setecentista (MARCOS, 2006, p.176). Caracterizando um processo de centralização, em última instância, só o rei poderia criar leis e nos casos de dúvida de interpretação, só ele poderia resolvê-las (MARCOS,2006, p.177). Ou seja, queria-se uma única interpretação, aquela conveniente e útil ao governo e para isso era preciso eliminar o "tradicional labirinto opinativo" retirando a autoridade das correntes jurídicas tradicionais que fragilizavam a vontade do rei (MARCOS,2006, p.181).

Um dos traços que diferenciam a razão seiscentista da razão iluminista consiste na tensão entre dois modelos ou formas de representação da sociedade e do poder: uma tradicional, que representa a sociedade como um corpo, e outra moderna, individualista (HESPANHA; XAVIER, 1998, p.113). Na Europa, até meados do século XVIII, havia uma pluralidade de normas leis e fontes do direito que dariam lugar a uma perspectiva centralizadora e utilitarista de acordo com as diretrizes do iluminismo. A concepção corporativista da sociedade baseia-se na cosmovisão medieval na qual havia uma ordem precedente aos homens e às coisas e que deveria ser reconhecida para o bom funcionamento da sociedade e de seus desígnios. Portanto, de uma maneira geral, havia uma concepção de natureza que fundamentava por sua vez uma noção de direito natural. 
Cada parte do todo tinha sua função e participava de uma forma diferente na realização deste destino cósmico (HESPANHA; XAVIER, 1998, p.114). Em uma sociedade bem governada, esta partilha natural deveria traduzir-se na autonomia político-jurídica dos corpos sociais.

Na linguagem jurídico-política medieval, a palavra que designa o poder era a palavra iurisdictio (o ato de dizer o direito). No século XVIII vai haver uma mudança de paradigma: deixa-se de pensar no poder enquanto a administração de uma ordem objetiva das coisas, o poder passa a ser concebido mais como um ato de vontade (HESPANHA; XAVIER,, 1998, p.117). Seja na vontade de Deus manifestada indiretamente na figura dos reis, seja na vontade de pactuar, o que daria lugar à corrente identificada como contratualista. A vontade, e não um equilíbrio preestabelecido, passa a ser o princípio que nortearia o direito. De acordo com a doutrina seiscentista, fundamentada em uma concepção corporativa do direito, os reis poderiam ser muitas vezes sujeitados pelas leis.

Entre o século XVII e XVIII ocorre uma mudança importante para a ideia de uma ordem legal e constitucional distinta, a do Estado, o qual o governante teria a responsabilidade de conservá-lo. Conforme apontam Hespanha e Xavier, embora nestes dois momentos houvesse uma tradição comum sobre as obras de moral, direito e política, “os modernos tendem a ler coisas diferentes dos tradicionais" (HESPANHA; XAVIER, 1998, p.113). Um importante divisor de águas é a imposição do princípio da utilidade como fundamento dos vínculos sociais. No modelo corporativista a moral e as virtudes se impõem perante a utilidade. No modelo corporativista conselhos e tribunais podiam se opor ao rei. O paradigma corporativista pressupunha a ideia de sociedade como um organismo em que cada parte do corpo coopera de forma diferente, caracterizada por uma autonomia político-jurídica dos corpos sociais. Dentro desta concepção a ideia de um poder concentrado no soberano era estranha. No paradigma corporativista não é o pacto que fundamenta o direito, é este que fundamenta a obrigatoriedade dos pactos (HESPANHA; XAVIER, 1998, p.115). O poder não é fundamentado no pacto, ou na vontade de pactuar, mas na forma originária (garantindo a autonomia) da organização social.

A ideia de direito natural, razão e natureza, remete aos gregos e foi sendo ressignificada ao longo do tempo em diferentes contextos sociais. Hespanha, por exemplo, identifica uma tradição jusnaturalista de raiz estoica difundida por Cícero, que se diferencia da aristotélica na forma como trata o conceito de natureza (HESPANHA, 2005, p.289). Em Santo Tomás de Aquino, o conceito de natureza e direito natural devem ser compreendidos no contexto em que os 
dogmas da Igreja orientavam toda a produção filosófica. Mais tarde, estas ideias assumiram um significado diferente e um papel fundamental na era moderna, tornando-se conceitos-chave para se compreender o movimento iluminista europeu e seu impacto nos diversos setores da sociedade.

Mas o que diferencia a percepção dos antigos sobre a razão quando comparada com a dos modernos? A confiança na razão vem principalmente das descobertas científicas, que de forma empírica, conseguem estabelecer nexos de causa e efeito acerca de determinados fenômenos naturais. Esta certeza vem através do uso da matemática; Galileu afirmava que Deus se comunicava por meio da natureza em linguagem matemática (ver BAUMER, 1977, p.68). E por isso observamos o impacto que as ideias de Newton causaram na república das letras. Newton nunca questionou a existência de Deus, mas sua explicação de alguns fenômenos da natureza (as leis de Newton) entrou em rota de conflito com a forma como a Igreja descrevia e explicava estes fenômenos. Por isso, o método da física experimental se tornaria um paradigma que também deveria ser adotado para explicar as questões do homem e da moral. Impunha-se a necessidade de pensar a política a partir da filosofia natural. O absolutismo de Hobbes era fundamentado na razão, o Leviatã foi baseado em uma teoria sobre a natureza do homem, sem fazer referência a Deus ou a qualquer ordem transcendente. $\mathrm{O}$ que não quer dizer que Hobbes era ateu, pois jamais duvidou da existência de Deus (SKINNER, 2010).

O direito natural moderno, identificado com a corrente do jusnaturalismo moderno, vai receber a influência de Descartes e da sua proposta de um método que pudesse oferecer mais certeza pelo uso da matemática e das evidências. Esta confiança na luz natural, base da recta razão, permitiria ao homem "ler" com mais certeza e precisão o grande livro do mundo, obra do Deus divino. A filosofia natural e o método científico passaram a servir de modelo para as ciências do homem, e também serão elementos importantes na caracterização do termo "boa razão". Assim, as ciências humanas deveriam utilizar o mesmo método das ciências naturais. Conforme apontou Cassirer, "Se Grotius ultrapassa a escolástica é menos, portanto, pelo conteúdo do seu pensamento do que pelo seu método. Ele vai realizar no domínio do direito a mesma revolução que Galileu realizou na física” (CASSIRER, 1992, p.325).

\section{Verney e o jusnaturalismo moderno}

Muitas ideias apresentadas no Compêndio e nos Estatutos também são 
encontradas na proposta de Luiz António Verney, sobretudo no seu polêmico Verdadeiro Método de Estudar (1746). Esta obra propõe um novo modelo de educação para o reino português em que se faz uma crítica pesada ao método escolástico utilizado pelos jesuítas. O Verdadeiro Método é constituído por um conjunto de cartas, cada uma tratando sobre uma disciplina específica, mas é na parte em que aborda a ética que encontraremos a presença recorrente do termo "boa razão". ${ }^{3}$ Para Verney, "lei que não é deduzida da boa razão não merece o nome de lei” (VERNEY, 1950,v. 3, p.261, grifo nosso). A falta dos princípios da boa razão ocasionava uma série de "embaraços", pois a maior parte dos juízes examinavam as leis sem se servirem do raciocínio, "só se servem da memória". Assim, como mencionado nos Estatutos, Verney também criticava o excesso de erudição, argumentando que ela deveria estar subordinada à "boa razão". Também destaca a importância do direito natural, que assume um papel central na jurisprudência, pois quem tem conhecimentos do direito natural julga melhor os casos não usuais, se comparado com aqueles que seguem apenas o que diz a lei, "julga melhor qualquer caso do que os que afectam esquisita erudição" (VERNEY, 1950,v. 3, p.263). O principal defeito dos juristas e dos moralistas portugueses consiste em que:

[...] Estes, comumente, não dão razão do que dizem, mas apontam somente os autores casuístas de onde o receberam, os quais nem menos assinam razão, mas fundam-se em outros antecedentes. E assim, copiando-se uns aos outros, multiplicam-se os livros sem necessidade, nem utilidade (VERNEY, 1950, v. 3, p.263).

Verney considerava a ética uma parte importante da filosofia, mas que no seu entender era desprezada em Portugal, por estar subordinada à teologia. ${ }^{4}$ Além de precisar ser integrada à filosofia, a ética deveria ser tratada como propedêutica da jurisprudência e da teologia. ${ }^{5}$ Além disso, na sua concepção, o direito natural estava inserido dentro da ética (VERNEY, 1950,v. 3, p.257-260). Enquanto a teologia tira suas conclusões das verdades reveladas, a ética é fundamentada na razão (VERNEY, 1950,v. 3, p.262). A ética é a parte da filosofia que mostra aos homens a verdadeira felicidade e regula suas ações para consegui-lo, é uma “coleção de preceitos que a luz de uma boa razão mostra serem necessários ao Homem para fazer ações honestas e também úteis à sociedade civil" (VERNEY, 1950, v. 3, p.254-259, grifo nosso). Para Verney, o direito natural representa uma nova abordagem sobre a justiça, não mais fundamentada exclusivamente 
na letra da lei, o que requer erudição, mas adequada aos ditames da filosofia moderna, cujo método inspirado nas descobertas das ciências da natureza, fundamentavam a verdade menos na autoridade dos textos (doutores) e sim nas evidências da observação e da experiência, o que corresponde a toda uma nova lógica e um novo método.

A publicação das críticas de Verney no seu Verdadeiro Método de Estudar gerou uma série de reações, principalmente por parte dos jesuítas. Por meio da publicação de folhetos e livros, eles e seus adeptos acusavam Verney de ser um traidor e inimigo da nação portuguesa. Dentre estas obras destacamos as Reflexões Apologéticas a obra entitulada Verdadeiro Método de Estudar, do jesuíta José de Araújo, escrita sob o pseudônimo de Frei Arsênio da Piedade. Nesta obra, Araújo defendia a superioridade da teologia perante a filosofia, alegando que somente a teologia teria competência para indicar os filósofos que "discorreram bem e aqueles que discorreram mal” (ARAÚJO, 1748, p.35). Araújo também defendia a importância da razão natural para se saber as obrigações do homem, os valores cristãos, mas também acreditava que a mesma razão natural deveria levar a certeza de que “existe apenas um só Deus”. Para ele o direito natural e o direito civil tem como fonte os ensinamentos de Deus e da Igreja (ARAÚJO, 1748, p.36). Araújo reiterava que os Teólogos também faziam uso da razão natural, mas que de fato não era o mais importante resolver a questão, mas mostrar os fundamentos. A busca pelos fundamentos, conforme argumenta Araújo, está ligada às famosas disputas e contendas do método escolástico, que foram atacadas obstinadamente por Verney, sobretudo quando envolviam o uso de silogismos. As críticas de Verney são similares àquelas apresentadas na "lei da boa razão" quando apontava para "posturas antiquadas”, "extravagantes sutilezas”, "palavras sediciosas” e "prejudiciais cavilações” com que alguns advogados portugueses, formados pelo método jesuíta de ensino, conduziam as demandas jurídicas.

Em resposta a Araújo, Verney criticava os doutores, moralistas, casuístas, em sua maioria seguidores da escolástica, por usarem de pouca razão e preferirem citar os doutores da Igreja: “E estas razões que dão, tiram-nas cegamente dos outros que citam, sem as deduzir da boa razão natural: e nenhum toma o trabalho de as examinar fundamentalmente" (VERNEY, 1748, p.49). Verney criticava a confusão dos escolásticos entre razão e revelação, insistia na necessidade de uma distinção entre verdades e juízos deduzidos pela razão e pela revelação. As virtudes sobrenaturais pertencem ao teólogo e as virtudes naturais do entendimento pertencem à ética (VERNEY, 1748, p.49). Assim, cabe 
à ética fundamentar-se na razão e a teologia na revelação (VERNEY, 1748, p.78). Vale ressaltar que Verney fala de uma “boa razão natural” para fazer distinção da razão natural escolástica, considerada por ele atrasada e ineficiente. Em sua argumentação, Verney deixa claro que ele considera que as virtudes morais podem ser induzidas mais facilmente pela razão natural e não pela revelação. Por isso a via da ética é o caminho mais curto para se atingir este objetivo, o que seria muito mais complexo pela via dos mistérios da revelação.

Verney também defendia a importância da boa razão no combate aos protestantes, considerados hereges e inimigos da verdadeira fé. Dotados de uma "profunda notícia da Ética, da Jurisprudência Natural, da melhor Filosofia, da Matemática”, os hereges estavam muito mais preparados para argumentar e convencer os jovens, não só por toda a Europa, mas em todas as regiões do mundo em que seus missionários atuavam (VERNEY, 1750, p.94). E para lutar contra eles, seriam necessários conhecimentos da Ética e saber com propriedade os princípios da religião católica. Para ser um bom teólogo é preciso "não só repetir o que leu, como Papagaio; mas resolver os casos com os princípios da boa razão". No sistema verneyano tudo converge para o conceito de método, baseado no método experimental da física newtoniana. Por isso, o estudante de direito, antes de iniciar o estudo das leis, deveria ter conhecimentos de física e de lógica (VERNEY, 1950, v. 4, p.175). O mesmo seria válido para a teologia, pois esta deveria provar os dogmas pela “boa lógica”, ou seja, pela “boa razão”. Aqui é possível perceber outros aspectos que caracterizam o sentido empregado por Verney quando faz uso do termo "boa razão”, a ideia de uma "boa lógica” e de uma "boa física".

No seu plano de ensino de ética, Verney recomenda alguns autores, como Grócio, mas sua preferência é por Pufendorf. Filho de um pastor luterano, Samuel Pufendorf viveu o período que marcou o fim das guerras religiosas que assolaram a Europa desde a Reforma Protestante. Neste contexto, surge a necessidade de se defender sociedades multiconfessionais, priorizando a paz social em detrimento da moral religiosa, o que levaria a Paz de Vestfália em 1648. A sociedade e suas convenções deveriam servir como fonte da moral e não a religião. Nesta consideração, Koselleck aponta para um processo de desestruturação da moral européia como conseqüência das fraturas sofridas pela Igreja Católica após a Reforma. Se antes havia uma identidade européia em torno de uma consciência moral, isso já não era mais possível a partir do século XVI. Se até então o campo moral teve a religião como sua fonte, esta vai progressivamente sendo substituída pela razão. A partir das guerras provocadas 
pelas divergências religiosas tornou-se imperativo a necessidade política da paz pelo soberano. Por isso, defende Koselleck, o ponto de partida do absolutismo foram as guerras religiosas, o Estado Absolutista emergiu para por fim à guerra civil e o iluminismo seria um movimento social em que o "campo da opinião" passou a se constituir como fonte da moral (KOSELLECK, 1999).

Assim como Grócio, Pufendorf procurou pensar sobre como organizar uma comunidade de povos e nações distintas independente da moral religiosa de cada um. Desde o século XVI, houve um esforço de construção teórica de uma política de Estado pautada pela razão, e não na religião, que se consolidaria no século XVIII. Isso é o que se costuma chamar de jusnaturalismo moderno ou jusnaturalismo racional. Tanto Grócio como Pufendorf, procuraram construir um direito que pudesse existir independentemente da moral cristã e que pudesse fundamentar uma teoria da sociedade internacional assentada no direito e não na teologia (PUFENDORF, 2007, p 38). Conforme aponta António Pedro Homem, até meados do século XVIII, predominou na Europa a ideia de que a teologia era a mãe de todas as ciências, e conseqüentemente, havia uma supremacia da teologia sobre o direito no plano do conhecimento (HOMEM, 2003, p.37).

Na sua obra Os deveres do homem e do cidadão, Pufendorf pretendia divulgar para um público mais amplo, especialmente aos jovens, conhecimentos básicos sobre o direito natural. Esta obra, cuja edição inglesa saiu com o título de The Whole Duty of Man, Accordingtothe Law of Nature (1691) teve grande repercussão na Europa, principalmente após ser traduzida para o francês por Jean Barbeyrac, em 1707, edição que influenciou outras edições inglesas até culminar com a de 1735. Para Pufendorf, o direito natural deveria ter os mesmos privilégios de outras ciências como o direito civil, a ética, a filosofia natural e a matemática.

Na obra Os deveres do homem e do cidadão, Pufendorf estabelece três fontes sobre o conhecimento do homem de seu dever, cuja principal diferença entre elas resulta das diferentes origens pelas quais derivam seus princípios. O direito natural, comum a todas as nações, que corresponde aos deveres do homem como "criatura sociável com o restante da humanidade"; o direito civil, que envolve as leis e Constituições dos países e corresponde aos deveres do homem como "membro de uma cidade ou comunidade" e a teologia moral, que versa sobre os deveres dos homens enquanto cristão. Pufendorf reconhece certa dificuldade em conciliar o direito natural e a teologia moral, sendo que o primeiro se refere a esta vida apenas, enquanto a teologia moral se refere a esta vida e o pósvida. O objeto principal do direito natural são as ações externas enquanto a 
teologia moral visa às ações internas (aquelas em que exteriormente parecem boas mas procedem de uma mente impura e corrompida) (PUFENDORF, 2007, p. 46). Seguindo as tendências do método experimental, as ações externas poderiam ser mais facilmente tomadas como objeto de análise por meio do método experimental, enquanto as ações internas, devido talvez ao seu caráter subjetivo, seriam muito mais difíceis de serem estudas por este método.

Pufendorf adverte que a teologia moral não trata com tanta frequência as ações que costumam aparecer nas leis humanas, mas aquelas que geralmente estão fora do alcance das leis e das constituições. Para ele, a proeminência do direito natural perante as demais fontes do direito vem da seguinte máxima: “Devemos ser humanos, antes de sermos cristãos; e quem não ouvir a voz da natureza não irá ouvir mais a voz da lei ou a do Evangelho” (PUFENDORF, 2007, p.469). Assim, a voz da razão é pré-requisito para se ouvir a voz da lei de Deus, assim como das leis e das constituições.

Embora Pufendorf reconheça certa complementaridade entre as duas, na medida em que as virtudes cristãs podem auxiliar na ordem social, sugere que o direito natural é mais importante e necessário para que o homem possa reconhecer ações que possam ser contrárias à comunidade e que atuem contra a paz (PUFENDORF, 2007, p.47). E assim, defende a ideia de que "a conduta do homem bom é em toda a parte a mesma" e que existe uma lei fundamentada na natureza dos homens, ensinada pela razão, uma lei perpétua e irrevogável, uma "lei universal da humanidade" (PUFENDORF, 2007, p.450). Por isso critica as leis baseadas no costume: "O costume é a opinião e a decisão de uma multidão cega, e não de sábios e sensatos” (PUFENDORF, 2007, p.445).

Embora Grócio e Pufendorf fossem autores fundamentais para o ensino do direito natural, Verney advertia para o fato de serem "hereges", e por isso recomendáveis apenas aos mestres. Contudo, mesmo assim, segundo ele, quem não tivesse outra opção, poderia ler Pufendorf. ${ }^{6}$ Esta postura de Verney pode ser relacionada com o que na historiografia costuma se chamar de "iluminismo católico" ${ }^{7}$, na medida em que havia o objetivo de uma modernização e laicização do Estado português, porém conservando os princípios do catolicismo. Por exemplo, embora Verney se posicionasse favorável a uma reforma da Inquisição, não defendia sua extinção, pois segundo ele era um Tribunal necessário para os portugueses para "conter as populações e evitar que elas, por superstição ou leviandade de espírito, caiam em doutrinas absurdas”. ${ }^{\circ} \mathrm{Na}$ perspectiva verneiana, a modernização deveria ser orientada a partir do que considerava medidas necessárias “proporcionadas ao estilo de Portugal”. Esta forma de filtro 
da modernidade, de adequação ao contexto específico português, talvez seja um elemento característico importante para a compreensão dos significados assumidos pelo termo "boa razão".

Em uma carta de Verney escrita para o iluminista italiano Ludovico Antonio Muratori, datada de dezembro de 1745 , um ano após a publicação da primeira edição do seu Verdadeiro Método de Estudar, afirmava concordar com o caráter severo da Inquisição portuguesa, mas que, contudo, não poderia ser considerado um Tribunal cruel. Demonstrando sua intolerância religiosa em relação aos judeus, no caso daqueles que diziam crer em Cristo, mas que continuavam a praticar o judaísmo clandestinamente, a Inquisição portuguesa "mandou apertar o pescoço e queimar depois de mortos", e ponderou: “[...] que vês tu em tudo isto que não seja justo, equitativo e consentâneo com as leis?" (MORAIS, 2006, p.133-134). Como podemos observar, no que se refere à religião, Verney defendia opiniões contrárias aos princípios defendidos por Grócio e Pufendorf, autores que, de certa forma, procuraram combater a intolerância religiosa na Europa. Para Verney, assim como para a maioria dos reformadores portugueses, a modernização do reino deveria ocorrer sem abalar a fidelidade à religião católica.

\section{A boa razão e o iluminismo católico}

Dentre os autores que deveriam ser evitados, Verney aponta uma lista extensa incluindo Maquiavel, Espinoza, Hobbes, Locke e também Barbeirac, principal divulgador da obra de Pufendorf na Europa. São autores que tem muita utilidade, mas que poderiam ser perigosos para os jovens estudantes e para aqueles que ainda não tivessem bem formados nos princípios da religião católica. Da mesma forma, embora os Estatutos recomendassem Grócio e Pufendorf como referências fundamentais do direito Natural, reforçava-se o papel da religião, advertindo que Pufendorf havia priorizado o estudo das leis naturais em detrimento de tópicos importantes como "a essência de Deus", “a imortalidade da alma" e a "vida eterna". Da mesma maneira, no seu tratado de direito natural, Tomás Antônio Gonzaga se afasta de algumas premissas de Grócio e Pufendorf por deduzir o direito natural a partir da ideia de Deus, entendido como a base de todo o direito (GONZAGA, 2004, p.15). O primeiro princípio apresentado em seu tratado parte da defesa da existência de Deus, seguindo a tese aristotélica de que deve haver uma "causa incriada", uma causa primeira. O direito natural seria então o conjunto de leis infundidas por Deus 
no coração dos homens e que são naturalmente acessíveis pela luz natural da razão (GONZAGA, 2004, p.10). A questão básica era saber se esse Deus era um Deus católico, protestante ou de qualquer outra religião. A grande maioria dos filósofos modernos não questionava mais a existência de Deus, mas considerava esta temática menos fundamental do que avançar no sentido daquilo que poderia ser conhecido por meio da razão e dos métodos científicos.

Na transição do século XVII para o XVIII, Paul Hazard apontou para a presença de uma crise de consciência, em que as certezas do homem vão sendo corroídas pelas ideias dos filósofos modernos (HAZARD, 1971). Basicamente, consiste na triste constatação de que não existe uma sabedoria além do alcance humano somente penetrável exclusivamente pela revelação, mas apenas aquela alcançável pela limitada razão. Este processo tem como pano de fundo a separação entre religião e filosofia, processo lento e gradual que marcou a transição do século XVII para o século XVIII. Embora as certezas da revelação tenham sido substituídas pelas incertezas da razão, havia um otimismo em relação ao século XVIII, a esperança de futuras felicidades pelo triunfo da razão sob a égide de um direito natural laico, emancipado da moral cristã.

Na medida em que avançamos em direção ao século XVIII, vai se impondo uma nova maneira de conceber o homem e a natureza. Assim como existiam leis naturais universais, como havia provado Newton, deveria haver leis universais que governassem a vida humana. A política deveria ser tratada pelo mesmo método da filosofia natural, e por isso a busca por verdades universais na justiça e na política (BAUMER, 1977, p.118). Esta questão, por exemplo, havia levado Hobbes, fascinado pelas ciências naturais, a considerar que assim como existiam leis que determinavam o movimento dos corpos naturais, deveriam existir leis que governassem o movimento dos corpos políticos (SKINNER, 2010, p.33 - 34).

A boa razão também estava articulada com o paradigma das ciências naturais, mas, em Portugal, teve maior expressão associada ao processo de centralização promovido pelo Marquês de Pombal, conforme as tendências do jusnaturalismo, procurando impor maior "racionalidade" aos processos jurídicos do reino. De acordo com António Pedro Homem, o jusracionalismo é uma nova forma de pensar o direito e o Estado, baseado na separação entre teologia e direito, por uma concepção secularizada do direito, tolerância religiosa, noção de ciência e método (HOMEM, 2010, p.37).

Em Portugal e Espanha, percebe-se uma maneira específica de se conciliar fé e razão, devido ao peso da Igreja Católica e pelo fato de terem sido reinos 
em que o contrareformismo teve forte expressão. Isso explica a intolerância de Verney e de alguns portugueses em relação aos judeus mesmo em tempos iluminados. Por isso, a expressão iluminismo católico passou a ser utilizada para fazer referência à especificidade do iluminismo português. Dentre outras características destacadas pela historiografia poderíamos apontar ainda o caráter reformista associado à figura do Marquês de Pombal e o papel de destaque que a educação teve neste movimento. Contudo, poderíamos destacar as raízes deste movimento que prepararam as reformas pombalinas. Conforme apontam Silva e Hespanha, a identidade católica dificultava a condução de uma "política nacional" que priorizasse as "razões de estado" (SILVA; HESPANHA, 1998, p.21). Por exemplo, o problema da intolerância aos judeus e o rigor excessivo da Inquisição em Portugal já haviam sido apontados pelo Padre Vieira no século XVII como elementos que afetavam o comércio do reino. O mesmo faria D. Luís da Cunha que observou uma crescente diminuição do comércio e uma "sangria" de população devido à Inquisição (CUNHA, 1820, p.53). ${ }^{9}$ Neste aspecto, a "razão de estado", de acordo com D. Luís da Cunha, consistia em conciliar a "utilidade temporal" do reino com a "utilidade espiritual da religião".

O ponto de contato entre estes portugueses é a defesa dos interesses do reino por meio de uma forma mais útil e racional de governar e administrar, e que também exigiria uma forma adequada de ensinar, e tudo isso estava articulado de certa forma com o conceito de "boa razão". Nesta análise, procurei compreender algumas formas de utilização do termo "boa razão" seguindo recomendações de Quentin Skinner quando aponta para a importância de recuperarmos o "alcance referencial" de uma palavra ou termo dentro de um contexto social específico, ou seja, trata-se de refletir não tanto sobre o seu significado, mas principalmente sobre os critérios de sua aplicação (SKINNER, 2005, p.257). Assim, foi possível observar como o termo "boa razão", para além da Lei de 18 de agosto de 1769, estava articulado com outras ideias do ideário iluminista português, como direito natural, ética, método e lógica.

O que podemos identificar nas ideias de Verney, na Lei de 18 de agosto de 1769 e nos Estatutos da Universidade é toda uma modernização do reino que pudesse acompanhar os tempos “iluminados". Este processo, contudo, deveria levar em conta a especificidade portuguesa, o que de certa forma encontramos de forma cristalizada no princípio da "boa razão". Era preciso repensar a finalidade da educação, que até então era voltada para a formação de um "perfeito cristão", para formar "homens úteis". Por meio das Luzes da "boa razão", seriam formados homens que pudessem julgar conforme as leis e aplicar a justiça com "bom 
senso”, de acordo as especificidades e necessidades do Estado português.

\section{Referências}

ANTUNES, Álvaro de Araujo. Pelo rei, com razão: comentários sobre as reformas pombalinas no campo jurídico. R. IHGB, Rio de Janeiro, v.172, n. 452, p. 15-50, jul./set. 2011.

ARAÚJO, José de. Reflexões apologéticas a obra intitulada verdadeiro método de estudar. Valência: Na oficina de Antonio Balle, 1748.

BAUMER, Franklin L. O pensamento europeu moderno: séculos XVII e XVIII. Rio de Janeiro: Edições 70, 1977. v. 1.

CASSIRER, Ernst. A filosofia do iluminismo. São Paulo: Editora da Unicamp, 1992. COSTA, Mário Júlio de Almeida. História do direito português. 2. ed. Coimbra: Almedina, 1996.

CUNHA, Luís da. Testamento político, ou, carta escrita pelo grande D. Luiz da Cunha ao senhor Rei D. Jose I antes do seu governo, o qual foi do conselho dos senhores $D$. Pedro I e D. João V., e seu embaixador às cortes de Viena, Haya, e de Paris; onde morreu em 1749. Lisboa: Impressão Regia, 1820.

GONZAGA, Tomás Antônio. Tratado de direito natural. São Paulo, Martins Fontes, 2004.Ordenações Filipinas. Disponível em: http://www1.ci.uc.pt/ihti/ proj/filipinas/ordenacoes.htm.Acesso em: 27 mar. 2020

HAZARD, Paul. Crise da consciência européia. Lisboa: Cosmos, 1971.

HESPANHA, António Manuel. Cultura jurídica europeia: síntese de um milênio. Florianópolis: Fundação Boiteux, 2005.

HESPANHA, António Manuel; XAVIER, Ângela Barreto. Representação da sociedade e do poder. In: MATTOSO, José (dir.). História de Portugal. Portugal: Estampa, 1998. v. 4.p.113-140.

HOMEM, António Pedro Barbas, História das relações internacionais: o direito e as concepções políticas na idade moderna. Coimbra: Almedina, 2003.

HOMEM, António Pedro Barbas. História das relações internacionais: o direito a concepções políticas na idade moderna. Coimbra: Almedina, 2010. 
JOSÉ I, Rei (comp.). Carta de roboração dos estatutos da universidade de Coimbra. In: JOSÉ I, Rei (comp.). Estatutos da Universidade de Coimbra. Lisboa: Regia OfficinaTypografica, 1772a.p. v - xii. Disponível em:https://books.google.com. br/books?id=FSfsE2VgkzEC\&pg=PR14\&dq=estatutos + da + universidade + de + coi mbra + livro $+i \& h l=p t-B R \& s a=X \& v e d=0 a h U K E w j R 5 c q 3 s r 3 o A h X C J 7 k G H W G R D w o$ Q6AEIRTAE\# $\mathrm{v}=$ onepage $\& \mathrm{q}=$ sobredita $\& \mathrm{f}=$ false.Acesso em: 28 mar. 2020.

JOSÉ I, Rei (comp.). Livro I: o curso theologico. In: JOSÉ I, Rei (comp.). Estatutos da Universidade de Coimbra. Lisboa: Regia OfficinaTypografica, 1772b. Disponível em: https://books.google.com.br/books?id=FSfsE2VgkzEC\&pg=PR14\&dq=estat utos + da + universidade + de + coimbra + livro $+\mathrm{i} \& \mathrm{hl}=\mathrm{pt}-\mathrm{BR} \& \mathrm{sa}=\mathrm{X} \& \mathrm{ved}=0 \mathrm{ahUKEwjR}$ 5cq3sr3oAhXCJ7kGHWGRDwoQ6AEIRTAE\#v=onepage \&q=estatutos\%20da\%20 universidade\%20de\%20coimbra\%20livro\%20i\&f=false.Acesso em: 28 mar. 2020.

JOSÉ I, Rei (comp.).Livro II: os cursos jurídicos das faculdades de Canones e de Leis. In:JOSÉ I, Rei (comp.). Estatutos da Universidade de Coimbra. Lisboa: Regia OfficinaTypografica, 1772c. Disponível em: https://books.google.com.br/books? id $=$ PHZTdPaBh9gC \& printsec $=$ frontcover $\& d q=$ estatutos + da + universidade $+\mathrm{de}+\mathrm{c}$ oimbra+livro+iI\&hl=pt-BR\&sa=X\&ved=0ahUKEwid56vMs73oAhVuD7kGHfzWA dwQ6AEILjAB\#v=onepage\&q=ORACULO\&f=false. Acesso em: 28 mar. 2020.

KOSELLECK, Reinhart. Crítica e crise: uma contribuição à patogênese do mundo burguês. Rio de Janeiro: EDUERJ: Contraponto, 1999.

MARCOS, Rui Manuel de Figueiredo. A legislação pombalina: alguns aspectos fundamentais. Coimbra: Almedina, 2006.

MAXWELL, Kenneth. O Marquês de Pombal: paradoxo do iluminismo. Rio de Janeiro: Paz e Terra, 1996.

MONCADA, Luís Cabral de. Um iluminista português do século XVIII: Luís António Verney. São Paulo: Saraiva \&C.a Editores, 1941.

MORAIS, Regina Célia de Melo. L. A. Muratori e o cristianismo feliz na missão do Paraguay.2006. 149f. Dissertação (Mestrado em História) - Universidade Federal Fluminense, Niterói, 2006.

ORDENAÇÕES FILIPINAS. Como se julgarão os casos, que não forem determinados pelas ordenações. [S. l.: s.n.], 1603. livro 3. Disponível em: http://www1.ci.uc.pt/ ihti/proj/filipinas/ordenacoes.htm.Acesso em: 27 mar. 2020. 
POMBAL, Marquês de. Compendio histórico da Universidade de Coimbra. Covilhã: Luso Sofiapress, 2011.Disponível em:http://www.lusosofia.net/textos/20111031marques_de_pombal_compendio_historico_da_universidade_de_coimbra.pdf. Acesso em: 28 mar. 2020.

PUFENDORF, Samuel. Os deveres do homem e do cidadão de acordo com as leis do direito natural. Rio de Janeiro: Topbooks, 2007.

SANTOS, Antonio Cesarde Almeida.Para a instrução dos homens encarregados dos negócios públicos no final do Antigo Regime português. In: FONSECA,ThaïsNivia de Lima e. (org.). As reformas pombalinas no Brasil. Belo Horizonte: Mazza Edições, 2011.p.205-226.

SILVA, Ana Cristina Nogueira; HESPANHA, António Manuel. A identidade portuguesa. In: MATTOSO, José (dir.). História de Portugal. Portugal: Estampa, 1998. v. 4.

SILVA, Antonio Delgado da.Alvará de reforma dos Estudos de 28 de Junho de 1759. In:SILVA, Antonio Delgado da.Legislação de 1750 a 1762. Lisboa: Na TypografiaMaigrense, 1830a.(Coleção da Legislação Portuguesa desde a última compilação das ordenações). p. 673-679.

SILVA, António Delgado da. Lei de Boa Razão, de 18.08.1769. Lisboa: TypografiaMaigrense, 1830b. 6 v.(Collecção da Legislação Portugueza desde a ultima compilação das ordenações). Legislation, bychronological ordem, between 1750 and 1820. Disponível em: https://www.fd.unl.pt/Anexos/Investigacao/7599. pdf. Acesso em: 27 mar. 2020.

SILVA, Nuno J. Espinosa Gomes da.Fontes do direito português.. 4. ed. Lisboa: Fundação CalousteGulbenkian, 2006. Fontes do direito.

SKINNER, Quentin. Hobbes e a liberdade republicana. São Paulo: Editora Unesp, 2010.

SKINNER, Quentin. Visões da política: sobre os métodos históricos. Algés: Difel, 2005

TELLES, José Homem Correia. Commentario crítico á Lei da Boa Razão, em data de 18 de agosto de 1769. Lisboa: Typografia de N. P. de Lacerda, 1824.

VERNEY, Luís António de. Respostas as reflexões que o R.P.M.Fr. Arsenio da Piedade Capucho fez ao Livro intitulado: verdadeiro método de estudar. Valência: 
Na oficina de Antonio Balle, 1748.

VERNEY, Luís António. Parecer do doutor ApolonioPhilomusoLisboense. Lisboa: [s. n.], 1750.

VERNEY, Luís António. Verdadeiro método de estudar. Lisboa: Livraria Sá da Costa Editora, $1950.5 \mathrm{v}$.

\section{Notas}

'Doutor em História pela UFPR. Professor do Centro Universitário Curitiba (Unicuritiba).

Sobre a influência da Lei da Boa Razão na prática dos agentes da administração da justiça ver: (ANTUNES, 2011).

${ }^{3}$ Ver Carta 11 Volume III. Na edição organizada pelo professor Salgado Junior (VERNEY, 1950) a obra é dividida em 5volumes.O volume I, intitulado Estudos Lingüísticos, contém as Cartas I (Introdução); II (Língua Portuguesa); III (Gramática Latina) e IV (Latinidade). O volume II, intitulado Estudos Literários, a Carta V (Línguas Orientais); Carta VI (Retórica) e Carta VII (Poesia). O volume III, Estudos Filosóficos, a Carta VIII (Lógica); Carta IX (Metafísica); Carta X (Física) e a Carta XI (Ética). O volume IV, Estudos Médicos, Jurídicos e Teológicos, a Carta XII (Medicina); Carta XIII (Direito Civil) e Carta XIV (Teologia). Por fim, o volume V, intitulado Estudos Canônicos, Regulamentação Sinopse, é constituído pelas Cartas XV (Direito Canônico) e XVI (Regulamentação geral dos Estudos).

${ }^{4}$ Para Verney, a Ética ou Filosofia Moral se divide em duas partes: A que trata do Sumo Bem e o modo de consegui-lo; e outra que expõe as diversas obrigações do homem que se orienta pela boa razão. Estas ações ou são honestas ou são úteis, nascendo outra divisão desta segunda parte. O Direito Natural - para Verney o mesmo que a Jurisprudência Natural ou Universal ou direito das gentes, trata das ações honestas e das obrigações do homem com Deus, para consigo e para os outros. A Prudência Civil ou Economia e a Política, que administra os problemas das cidades e dos reinos, trata das ações úteis.

${ }^{5}$ Para Verney a ética é a lógica da Teologia Moral e Jurisprudência, a ética deduzida da boa razão, excita nos Homens os princípios do direito natural (VERNEY, 1950, v. 3, p.260).

${ }^{6}$ Verney aponta a necessidade de um compêndio de Ética adequado às necessidades de Portugal. Faz alusão a certo amigo que estaria escrevendo uma Ética que deveria ser publicada. Sabemos que estava falando de seus compêndios. Verney escreveu um compêndio de Metafísica e outro de Física que chegaram a ser publicadas. A Ética provavelmente se perdeu e nunca foi publicada.

O termo "iluminismo católico" é atribuído a Cabral de Moncada que considerava que o Iluminismo havia se propagado de formas distintas para cada região da Europa, mas que os países católicos, como Itália, Espanha e Portugal seguiam características comuns: "Este Iluminismo era assim, pode dizer-se, essencialmente Reformismo e Pedagogismo. O seu espírito era, não revolucionário, nem anti-histórico, nem irreligioso, como o francês; mas essencialmente progressista, reformista, nacionalista e humanista. Era o Iluminismo italiano" (MONCADA, 1941, p. 12).

${ }^{8}$ Carta escrita de Verney a Muratori de Roma em dezembro de 1745, Morais (2006, p. 133). 
${ }^{9}$ De acordo com D. Luís da Cunha, um dos fatores que compõe a riqueza dos reinos é sua população. Por isso chamava a atenção para a "sangria" de gente provocada pela Inquisição. 